\title{
TO BEAT OR ABET IN MACHADO DE ASSIS'S "PAI CONTRA MÃE": THE TEXT IN SUPERPOSITION
}

\section{CHRISTOPHER T. LEWIS}

University of Utah

Salt Lake City, Utah, Estados Unidos

\begin{abstract}
In Machado de Assis's "Pai contra mãe," the first of Cândido Neves's many aborted professions - typesetting - takes on an unexpectedly clairvoyant dimension when one considers a critical textual variant: the addition of a cedilha to a pivotal word in some editions of the story. When we review this typographical discrepancy in light of the context of race relations and slavery in Machado's prose fiction, it not only becomes a microcosm of the contrapuntal nature of "Pai contra mãe," but it also serves as an avatar for the importance of reader engagement in the central ambiguity of Machado's best work.
\end{abstract}

Keywords: "Pai contra mãe"; typo; ambiguity; slavery; translation

\section{ACOITAR OU AÇOITAR EM "PAI CONTRA MÃE": TEXTOS EM SOBREPOSIÇÃO}

Resumo: Em "Pai contra mãe", de Machado de Assis, a primeira das diversas profissões abortadas por Cândido Neves - composição tipográfica-assume uma dimensão inesperadamente clarividente ao se considerar uma significativa variante textual: a adição de uma cedilha a uma palavra crucial em algumas edições do conto. Quando analisamos essa discrepância tipográfica à luz do contexto das relações raciais e da escravidão na ficção em prosa de Machado, ela não se torna apenas um microcosmo da natureza contrapontística de "Pai contra mãe", mas serve também de avatar para a importância do engajamento do leitor diante da ambiguidade central presente nas melhores obras de Machado.

Palavras-chave: "Pai contra mãe"; erro tipográfico; ambiguidade; escravidão; tradução 

short story collection he published during his life, Relíquias de casa velha (1906), the narrator notes that Cândido Neves "não aguentava emprego nem ofício, carecia de estabilidade; é o que ele chamava caiporismo. Começou por querer aprender tipografia, mas viu cedo que era preciso algum tempo para compor bem, $[\mathrm{e}]^{1}$ ainda assim talvez não ganhasse o bastante $[. . .]^{\prime \prime}$ (ASSIS, 2015g, p. 621-622, emphasis mine). Anyone familiar with "Pai contra mãe" knows that Cândido Neves eventually finds some measure of success as a slave catcher. However, the first of his many aborted professions typesetting - takes on an unexpectedly clairvoyant dimension in view of a critical textual variant: the addition of a cedilha to a pivotal word in some editions of the story.

When we review this typographical minority report in light of the context of race relations and slavery in Machado's prose fiction, it not only becomes a microcosm of the contrapuntal nature of "Pai contra mãe," but it also serves as an avatar for the importance of reader engagement in the central ambiguity that Machado is known for in his best work. As he himself prophesies in the "Advertência" at the beginning of Reliquias de casa velha, we will see how the text's relationship to the tension between "to beat or abet" - referred to in the title of this article - "Depende da tua impressão, leitor amigo, como dependerá de ti a absolvição da má escolha" (ASSIS, 2015a, p. 620).

\section{Slavery in the Machadian Context}

Explicitly black characters do not play leading roles in the vast majority of Machado's work, especially if one factors out the broader question of mulato ancestry and narrows the discussion to enslaved Afro-Brazilians. Raimundo in Iaiá Garcia and Prudêncio in Memórias póstumas de Brás Cubas are the most fully developed examples in his novels, which, considering how fleeting their appearances are, sets a low bar. Ressurreição, A mão e a luva, Helena, and Dom Casmurro include only the briefest of mentions of slaves. Quincas Borba and Esaú e Jacó contain little more than that though the latter, as well as Memorial de Aires, do address the (white) political aspect of abolition.

\footnotetext{
${ }^{1}$ The 1975 Civilização Brasileira definitive critical text has an "e" before "ainda," which has been absent in the Nova Aguilar Obra completa since the 2008 edition.
} 
Most of the short stories also do not go beyond scant allusions - such as the "preto velho que o servia" who makes a couple of appearances in "Um homem célebre" (ASSIS, 2015h, p. 452) or the "preto velho e míope" that assists Procópio with the colonel's burial shroud in "O enfermeiro" (ASSIS, 2015e, p. 483). In "Entre santos," an avaricious man posthumously frees a slave to avoid paying for her burial. Slaves garner a small amount of direct attention from the protagonist in "O espelho," though he disparages them as "espíritos boçais," "pérfidos," "malvados," and "velhacos" (ASSIS, 2015f, p. 316). "Vidros quebrados," "Verba testamentária," and "Virginius" recount cases of explicit violence against slaves, and the last of these even tells a substantial amount of the story from a slave's point of view.

Although much can still be read into some of the above examples, the short stories "Mariana," from 1871 (the first of two stories Machado wrote with that title), "O caso da vara," from 1891, and "Pai contra mãe," from 1906, are the most prominent texts in Machado's prose fiction that engage slavery more directly. Moreover, these three stories have all seen their critical fortunes rise as interest in the presence and portrayal of Afro-Brazilians in Machado's work has increased over the last several decades. Significantly, both "Mariana" and "O caso da vara" share the same tension represented by the title of this article - "to beat or abet" - with "Pai contra mãe."

In "Mariana," the titular slave, raised as a member of the family, falls in love with the heir, Coutinho. When Coutinho becomes engaged to his cousin (who, it is implied, might even be Mariana's half-sister), Mariana runs away on two occasions to escape a situation that is causing her considerable suffering. ${ }^{2}$ Both times, Coutinho tracks her down and threatens to have the authorities drag her home by force. In the first instance, he manages to convince her to return willingly, but in response to his threats the second time, she ingests poison and dies. ${ }^{3}$ In "O caso da vara," young Damião runs away from seminary and takes refuge at the house of the widow Sinhá Rita, who is romantically linked to his godfather, João Carneiro. Though Rita gives Damião unwavering support and kindness, promising to make Carneiro intercede with his father, she is cruel to Lucrécia, an eleven-year-old slave girl in her household. Damião feels sympathy for the child and privately resolves to protect her. However, in the story's final moments, Rita calls for

${ }^{2}$ Coutinho hints that he at least considers abusing Mariana sexually: "Confesso, entretanto, que, apesar de não compartir de modo nenhum os sentimentos de Mariana, entrei a olhar para ela com outros olhos. [...] Além disto, surgiu em meu espírito uma ideia, que a razão pode condenar, mas que nossos costumes aceitam perfeitamente" (ASSIS, 2015c, p. 984).

${ }^{3}$ Note the parallels with Machado's poem "Sabina," from Americanas (1875). 
him to bring her the rod she uses to punish Lucrécia, and Damião's selfinterest gets the better of his sense of mercy: "Damião sentiu-se compungido; mas ele precisava tanto sair do seminário! Chegou à marquesa, pegou na vara e entregou-a a Sinhá Rita" (ASSIS, 2015d, p. 529). In both stories, Coutinho and Damião find themselves in a position to offer aid to defenseless slaves for whom they feel compassion, but instead become complicit in the culture of violence against them - a culture that breeds characters, in the words of Reginald Daniel (2012, p. 87), "lacking in any sense of responsibility."

At the climax of "Pai contra mãe," the protagonist Cândido Neves grapples with similar circumstances in regard to a runaway slave named Arminda. Before arriving at this ethical dilemma, however, the story begins with expository material about instruments for controlling and punishing slaves in the 1850s, such as the tin mask and the iron collar. The narrator then proceeds to the subject of runaway slaves and the measures taken to recover them, including newspaper notices, proffered rewards, and the vocation of the slave catcher, which is how Cândido Neves earns his living. He is an amiable man who loves his wife, but, after failing to persevere in any steady profession - such as his unsuccessful foray into typography - he has resorted to slave catching due to the financial pressure of supporting an expanding family.

After Cândido and his wife, Clara, have a son, their financial situation worsens and they are evicted. His wife's aunt Mônica, who lives with them, manages to procure some basement rooms behind a stable, where they are allowed to stay out of charity. Nevertheless, things have become so desperate that she convinces the young couple that they must give up their child to the foundlings' wheel at the convent for its own survival. ${ }^{4}$ As Cândido makes his way there, he comes across the runaway Arminda, who he knows will fetch a sizable reward. Leaving his son with a pharmacist, Cândido confronts her. She begs for mercy, pleading that she is pregnant and that her senhor will beat her. She appeals to his empathy as a fellow parent: "Se vossa senhoria tem algum filho, peço-lhe por amor dele que me solte [...]" (ASSIS, 2015g, p. 626).

\footnotetext{
${ }^{4}$ In what later becomes thematically significant, the text implies that aunt Mônica had previously suggested a late-term abortion: "- Não, tia Mônica! - bradou Candinho, recusando um conselho que me custa escrever, quanto mais ao pai ouvi-lo. - Isso nunca!" (ASSIS, 2015g, p. 624). The em dash before "Isso nunca!" does not appear in the definitive critical text but has been present in the Nova Aguilar Obra completa since 2008.

5 The definitive critical text reads "Vossa Senhoria." The Nova Aguilar Obra completa removed the capitalization in 2008 .
} 
However, like Coutinho and Damião, when faced with the choice between aiding Arminda (abet) or delivering her up to violence (beat), Cândido Neves opts for the latter and forcefully drags her back to her master's house. As he is collecting his reward, she suffers a miscarriage at the threshold of the front door, brought on by her violent struggle. His son now saved, Cândido justifies his actions in his heart by reminding himself that "Nem todas as crianças vingam [...]" (ASSIS, 2015g, p. 627). Not only is Cândido's behavior reminiscent of "Mariana" and "O caso da vara," but all three stories speak to Robert Newcomb's (2008-2009, p. 44) observation that, in "Pai contra mãe," "Machado illustrates how slavery provides the occasion for the flaws and contradictions inherent in human nature and society to manifest themselves to fatal effect [...]".

Naturally, the most common interpretations of this story center on race - specifically, as Eduardo Duarte (2007b, p. 143) articulates it, "how the death of the black child provides the 'salvation' of a white child [...]" as a representation of the greater social and racial forces at play. Célia Lima and J. Rodrigues's (2003) graphic novel adaptation portrays this quite literally, depicting Cândido and Clara Neves as recognizably Caucasian. While on a symbolic level this is a defensible reading, it ignores a lot of information in the "entrelinhas." At a minimum, it is true that a slave's baby was sacrificed for a free man's son. However, as Alex Flynn, Elena Calvo-González, and Marcelo Mendes de Souza (2013, p. 5) observe, "Machado's text is not prescriptive; the author's intention is rather to invite the reader into what amounts to a common misreading and thereby demonstrate that the solidity of whiteness, which many take for granted, is in fact negotiable and socially constructed." Thus, as they suggest, it is more likely that the principal distinction between Cândido and Arminda is not racial, only legal.

First and foremost, it is by no means clear that Cândido is white. His occupation as a slave catcher is hardly proof of that. As Fernando Sousa de Rocha (2016, p. 95-96) notes, such was the spectrum and ambiguity of appearance among the enslaved and poor free population that "there were cases in which slave catchers [...] were arrested under the suspicion of being themselves runaway slaves." In addition, as in stories like "Um homem célebre," Machado imbues the text with subtle clues about the characters' race (WISNIK, 2008). Most prominently, Cândido and Clara Neves joke about the whiteness implied by their own names and surname, which makes most sense if they are reacting to the irony of their racial background. Besides, the narrator describes Cândido Neves's propensity for changing 
occupations as "um modo de mudar de pele ou de pessoa" (ASSIS, 2015g, p. 624 , emphasis mine), as if a more respectable line of work could affect how he is perceived in racial terms and thus provide the possibility for social ascension. ${ }^{6}$

Clara works as a seamstress, another profession that is associated with social and racial categories not very far removed from slavery. Raymundo Faoro (1976, p. 322) highlights this when he comments that Cândido and Clara inhabit the space of "os párias do serviço doméstico, criados, cocheiros e costureiras, mal diferenciados do escravo, como este dependentes, ou mais, da afeição ou da malquerença do patrão." For them, he concludes, "a liberdade é apenas ilusão" (FAORO, 1976, p. 326). The text supplies evidence of this when, on one occasion, Cândido inadvertently tries to apprehend a free man. As a result, it is he who receives a beating at the hands of the man's relatives. That they dare to strike him speaks volumes about where they perceive Cândido's position in the class hierarchy to be. The fact that the whip has symbolically been turned on him further emphasizes his socioracial proximity to the runaways he pursues.

Just as Machado never makes Cândido and Clara's racial background explicit, David Brookshaw (1986, p. 180) points out that he did the same for himself. Racial characterizations of Machado have shown a certain pliability over time, ranging from whitewashed Greek to an icon of black power (GUIMARÃES, 2017b, p. 16, 23-24). Predictably, opinions on his approach to race and slavery track a similar gamut. Some of the harshest and most famous critiques are not verifiable, such as Luís Murat's provocative but dubious claim that José do Patrocínio despised Machado as a hater of his own race (MAGALHÃES JÚNIOR, 1957, p. 145-151) or the mocking triolet attributed to Cruz e Sousa (MACHADO, 2007). However, there is no doubt about the authenticity of Mário de Andrade's (1950-1959, p. 104, 107) 1939 essay, in which he writes that Machado "traiu bastante a sua e a nossa realidade" and "Viveu moral e espiritualmente escanchado na burguesice do seu funcionarismo [...]". As Giorgio Marotti (1987, p. 113) sums up the indifference some have ascribed to him, "Machado never fought against slavery because he never fought against or for anybody."

On the other hand, Raymond Sayers (1956, p. 208) points out that Machado was complimentary of others' more politically-minded literary endeavors, even if they did not fit the style or temperament of his own pen.

${ }^{6}$ The narrator makes a related observation about Cândido's landlord, saying that "Ao vê-lo, ninguém diria que era proprietário," which carries possible racial undertones (ASSIS, 2015g, p. 625). 
Instead, the stories cited previously illustrate that, as Paul Dixon (2010, p. 40) commented, "rather than ignoring social problems, Machado was intensely aware of them, and [...] he wrote to denounce them, although in ways more subtle and ironic than most of his contemporaries." Furthermore, Duarte (2007a, p. 241-242) argues that what Machado does not say is revealing. Never in any of his writings does he show evidence of the common racist perspectives of his day that even some abolitionists held. Moreover, an oblique approach to Afro-Brazilian issues is absolutely consistent with his usual methods of contributing to the discourse on any subject. As Duarte (2007b, p. 150) remarks, he was merely "conscious of his weapons and his targets."

With all this in mind, the idea that Cândido and Arminda belong to a similar social and racial category opens up a lot of interpretational space for "Pai contra mãe." For one thing, all three of the stories we have examined are not just about slavery, but also the subjugation of women. In "Pai contra mãe," this tension is encoded in the title, but by hinting at how much Cândido and Arminda have in common, the text draws even greater attention to the gender dynamics at play. One of the key takeaways from this story is that, at any level of society, a man still has the power to sentence a woman to violence. ${ }^{7}$

Along these lines, Nicolau Sevcenko proposes "Pai contra mãe" as an inversion of the Christmas narrative, which he considers an account of human generosity. ${ }^{8}$ For example, in Bethlehem, a homeless woman expecting a baby is given shelter. Shepherds and wise men come to honor a child whose legitimacy is questionable. Most importantly, Christmas represents a birth to free one's people from enslavement. To be sure, the last profession Cândido Neves abandons before turning to slave catching is that of a wood carver. He, like Joseph, comes face to face with a woman bearing what we assume to be an illegitimate child, as the law would define it. Arminda, wanting to give her child the Phrygian cap of the wise men instead of the implements of slavery the story describes, is thrown upon Cândido's generosity. As is the case with Mary and Joseph, the authority to grant her refuge or cast her upon the law, to be stoned, is reserved for a man.

In more ways than one, Cândido sits at the nexus between beat and abet, evoked by the titles of "O caso da vara" and "Mariana" (Marianne, the

${ }^{7}$ Of the other stories briefly mentioned at the beginning of this section, see especially "Virginius."

${ }^{8}$ Class lectures on February 21 and 28, 2008 as part of the course Urban Explosion: City and Culture in Rio and São Paulo (Portuguese 266), Department of Romance Languages \& Literatures, Harvard University. 
Phrygian cap-wearing French icon of liberty), respectively. He has known the sting of a whip himself and his own wife gave birth in something resembling a stable due to the compassion of others. Now he has the opportunity to save Arminda and her child. Though Cândido's and Arminda's legal situations are different in terms of who is technically free or enslaved, because they are part of the same oppressed, subservient class, one can see how Cândido Neves's circumstances could lead him to feel empathy for Arminda. If he gave her aid, the birth of her child might be regarded as the coming of a Messiah, in a sense. This would not be a Messiah incarnated as a military leader to free Jews from Romans or a savior to redeem sinners from hell - but rather manifested in a gesture of defiance against a system that turns people on their own, as a refusal to be complicit in forces that pit a father against a mother or a Joseph against a Mary.

But of course, in this "microcommunity of Afro-descendants who control, punish, and annihilate each other for the benefit of white elites," there is no generosity, no room at the inn (ROCHA, 2016, p. 101). There is no Natal, only miscarriage. Like the poetic stillbirth of Machado's own "Soneto de Natal," "all that remains is the lacuna" (LEWIS, 2016, p. 559). Instead, Cândido plays the role of a premature Judas, giving up one of his own for money. He denies grace to the slave, to the woman, and hoards it only for himself and his child. When faced with the choice of "to beat or abet," whether as an individual, a token of human nature, or a $\operatorname{cog}$ in abusive systems, Cândido reacts in the same way as Coutinho and Damião.

\section{The Typographical Fulcrum}

Similar to a biblical narrative's many source texts, translations, and inconsistencies over the centuries, "Pai contra mãe" also bears an interesting textual variant that speaks to its essence as well as Machado's best prose fiction. In the Garnier first edition, the fourth paragraph of the story, which describes newspaper advertisements offering rewards for the capture of runaway slaves, reads like this:

Quem perdia um escravo por fuga dava algum dinheiro a quem lh'o levasse. Punha annuncios nas folhas publicas, com os signaes do fugido, o nome, a roupa, o defeito physico, se o tinha, o bairro por onde andava e a quantia de gratificação. Quando não vinha a quantia, vinha promessa: «gratificar-se-ha generosamente,» - ou «receberá uma boa 
gratificação.» Muita vez o annuncio trazia em cima ou ao lado uma vinheta, figura de preto, descalço, correndo, vara ao hombro, e na ponta uma trouxa. Protestava-se com todo o rigor da lei contra quem o acoutasse (ASSIS, 1906, p. 4).

Over the years, editors and publishers have modernized the spelling, accentuation, and punctuation to reflect evolving standards. The changes are exactly what one would expect, such as the substitution of the guillemets with quotation marks, the second of which is now usually placed before a comma or period. Typically, the most drastic alteration is that many editions update "acoutasse" to "acoitasse," including the latest Nova Aguilar release (2015) of Machado's complete works.

Curiously, however, some versions contain another, more consequential permutation. As if the careless, aspiring typographer Cândido Neves himself had set the type, to the last word of this paragraph "acoutasse" - has been added a cedilha, rendering it "açoutasse." To my knowledge, this first occurred in a 1963 edition of Relíquias de casa velha, published by the Instituto de Divulgação Cultural in São Paulo - which uses "açoitasse" (ASSIS, 1963b, p. 10). ${ }^{10}$ Yet the most prominent editions that contain this modification are these: 1) a 1980 anthology of Machado's short stories entitled $O$ conto de Machado de Assis, edited by Sônia Brayner and published by Civilização Brasileira; and 2) the Machado de Assis entry in Global Editora's "Melhores Contos" series, first published in 1984, with the selection and preface by Domício Proença Filho:

Sônia Brayner anthology:

"Protestava-se com todo o rigor da lei contra quem o açoutasse" (ASSIS, 1980, p. 283, emphasis mine).

Domício Proença Filho anthology:

"Protestava-se com todo o rigor da lei contra quem o açoitasse" (ASSIS, 1994, p. 250, emphasis mine).

I call these collections prominent not only because they carry the names of well-known academics on their covers, but also for bibliographic

\footnotetext{
${ }^{9}$ The first instance of the diphthong change from ou to oi appears to be the $1955 \mathrm{~W}$. M. Jackson Obras completas, though both are common in contemporary editions.

${ }^{10}$ Like other, later versions of Relíquias de casa velha, this edition comprises two volumes because, in addition to the stories from the original, it also includes thirty-three others that only appeared in periodicals during Machado's lifetime.
} 
reasons. For one thing, they both affirm the accuracy of the text by explicitly citing as their source the definitive version established by the Comissão Machado de Assis, which was published in a 1975 critical edition by Civilização Brasileira in conjunction with the Instituto Nacional do Livro (and does not contain the cedilha). They also both appear in the (skeletal) bibliography in the Nova Aguilar complete works. Whatever the reasons for this editorial decision, their presence on the list represents both evidence of, and a contributing factor to, their relative prominence.

Brayner's collection has only two editions (1980 and 81), both with the cedilha. The Global anthology remains in print with sixteen editions and counting, though, remarkably, the discrepancy does not appear until the ninth edition in $1994 .{ }^{11}$ Nevertheless, it persists in every subsequent release over the last twenty-four years, encompassing seven more editions and a widely circulated digital version. ${ }^{12}$ It is likely that this has helped to facilitate the cedilha's spread into many other contexts. Even some vestibular and Enem prep materials now include it, usually with erroneous citations - such as to John Gledson's 50 contos de Machado de Assis or Ítalo Moriconi's Os cem melhores contos brasileiros do século, though the cedilha appears in neither. Still, perfectly respectable print editions do continue to reproduce it, as is the case with the Rinaldo de Fernandes-edited Capitu mandou flores (Geração Editorial, 2008), or the published draft script of the film Quanto vale ou é por quilo? (Imprensa Oficial do Estado de São Paulo, 2008), which provides the story as an appendix..$^{13}$

As typos go, this one is especially perilous because it alters the substance of the sentence in a way that not only still makes perfect sense, but also results in the opposite meaning. As a reflection of the moment of decision faced by Coutinho, Damião, and Cândido Neves, as well as this article's title, açoitar means to whip or beat while acoitar means to give refuge. The three most recent English translations of the story illustrate the latter. As John Gledson translates the passage, it reads: "Anyone who gave the slave shelter was threatened with the full rigour of the law" (ASSIS, 2008,

11 The ninth edition is "revista e ampliada" to include minor edits to Proença's introduction, the addition of two stories that did not appear in previous editions ("Capítulo dos chapéus" and "Entre santos"), a brief biographical sketch of Machado, and an updated overall design and layout.

12 Despite continued updates to the formatting over the years, the $16^{\text {th }}$ edition (2010) and its subsequent reprints (the most recent I examined was the third, from 2015) still contain the cedilha. As of this writing, the e-book currently available for purchase (based on the $16^{\text {th }}$ edition) does also.

${ }^{13}$ In addition to the cedilha, the version in the Quanto vale script dispenses with the quotation marks in the same paragraph, adds italics in various places, and misidentifies the story's source as Contos fluminenses. 
p. 256, emphasis mine). John Charles Chasteen opts for "They invoked the full rigor of the law against anyone who aided or abetted the escape" (ASSIS, 2013, p. 63, emphasis mine). A new translation of the story by Margaret Jull Costa and Robin Patterson, in their forthcoming volume The Collected Stories of Machado de Assis, renders it "It also carried a warning that anyone sheltering the runaway would feel the full force of the law" (ASSIS, 2018, manuscript, emphasis mine). As for my word choice in the title, it is true that "abet," strictly speaking, refers to aiding someone in committing a crime. However, I have chosen to use it as the English stand-in for acoitar because 1) it fits the narrative context (see Chasteen's translation); and 2) most importantly, as with "açoitar vs. acoitar," "beat vs. abet" retains the symbolism of a minor typographical difference that transforms meaning.

In fact, there is an argument that açoitar is also perfectly logical since, in the previous paragraph, Machado points out that some senhores did not beat their slaves because a sense of ownership moderated their treatment of them. ${ }^{14}$ Therefore, in context, one can reasonably see how a reader might understand the text to mean that the law would punish a person for damaging someone else's so-called property, whether the cedilha is present or not. As it turns out, sometimes people even cite the passage correctly, without the cedilha, but then in their subsequent comments make it clear that they read the passage to mean açoitar all along. ${ }^{15}$ Even prominent Machado scholars are not immune to this. As a very significant case in point, here is how Helen Caldwell translates the sentence in the first English translation of the story, published in 1963: "And it [the notice in the paper] threatened to prosecute to the full measure of the law anyone who beat him" (ASSIS, 1963a, p. 102, emphasis mine). Logistically, it is nearly impossible that the Instituto de Divulgação Cultural edition from the same year could have been her source text, so the translation most likely indicates how

14 "[...] o sentimento da propriedade moderava a ação, porque dinheiro também dói" (ASSIS, 2015g, p. 621). Cf. Newcomb (2008-2009, p. 51-52) for exegesis on the significance of the word "propriedade" here vis-à-vis the concepts of "property" and "propriety" in society at the time.

15 To give a representative example, João Irineu de França Neto, in his MA thesis on slavery in Machado's short stories, quotes the passage in question, correctly reproducing "acoutasse." Nevertheless, in his commentary that immediately follows, he interprets it thus: "Isto é, quem açoitasse um escravo sem ser dono do mesmo estava cometendo um grave crime" (FRANÇA NETO, 2008, p. 102-103, emphasis mine).

However, I hasten to add the following caveat: No one is immune to typos, and I am acutely aware of how easily an article can become a glass house. One should not over-interpret an errant cedilha, mental or in print, as indicative of the overall quality or value of anyone's work. See also notes 20 and 23. 
Caldwell read and interpreted "acoutasse."16 This was the only English translation of the story available in print for the next forty-five years, until Gledson's was released in 2008. In addition, two years before Gledson's was published, Caldwell's translation was reprinted, without alteration, in the Oxford Anthology of the Brazilian Short Story. As a result, the newer translations notwithstanding, the ghost of the cedilha remains well represented in English. Moreover, it is not just bilingual, but a true polyglot. One year after Caldwell's version came out, Curt Meyer-Clason made the same mistake in the oft-reprinted German translation, "Vater gegen Mutter": "Das Inserat endete mit der Warnung: > Jede Mißhandlung des Sklaven wird gerichtlich verfolgt! $<$ [The ad ended with the warning: "Any ill-treatment of the slave will be prosecuted!"] (ASSIS, 1964, p. 294). Meyer-Clason's choice of Mißhandlung conveys the idea less literally than a verb like auspeitschen, for example, but it is nevertheless clear that he, like Caldwell, interpreted the text to mean açoitar even in the absence of the cedilha. ${ }^{17}$

${ }^{16}$ Helen Caldwell's correspondence in Portuguese suggests that her command of the language was dictionary dependent (GUIMARÃES, 2017a, chapter 3). If this is true, her error may not have been one of interpretation as she read, but rather the result of consulting the wrong dictionary entry. I have been able to inspect Caldwell's copy of the 1881 Diccionario Contemporaneo da Lingua Portugueza (known as the Dicionário Caldas Aulete). The definitions for "acoitar" and "açoitar" are both entirely correct and entirely ordinary (see v. 1, p. 27). Caldwell preserved it exceptionally well and made no marginal notes.

Frederick G. Williams obtained Caldwell's dictionary when he was on the faculty at the University of California at Santa Barbara. According to his recollection, a family member of Caldwell's contacted him, "proposing to donate" her Machado de Assis library, which consisted of her own books, those of other critics, a set of the 31-volume W. M. Jackson Obras completas, and the dictionary. Some of the collection became part of the library at UCSB's Jorge de Sena Center and it was agreed that Williams could keep any duplicates, which included the dictionary (WILLIAMS, 2017). Williams later donated what remained of Caldwell's books to the library at Brigham Young University (where he retired) and passed the dictionary to his colleague, Vanessa Fitzgibbon, who allowed me to examine it.

It is worth pointing out that no edition of the W. M. Jackson Obras completas contains the cedilha. However, Caldwell owning it in no way proves that she used it as her source text, just as the fact that the Dicionário Caldas Aulete was in her possession would not have precluded her use of others.

${ }^{17}$ While it is not impossible that Meyer-Clason consulted Caldwell's version or had access to the 1963 Instituto de Divulgação Cultural edition, it would be an extraordinarily quick turnaround for either. The most reasonable assumption is that Caldwell and Meyer-Clason both arrived at the same interpretation independently. Of the eighteen different translations I have looked at in English, Spanish, French, Italian, German, Dutch, and Russian, only Caldwell and Meyer-Clason understood the text to mean açoitar (see appendix). In Russian, the translator, В. Никонова [V. Nikonov], did not translate the word at all, as the first five paragraphs of the story are omitted entirely. The Russian edition's illustration of Cândido capturing Arminda is also worth mentioning because, like Lima and Rodrigues's depiction, it flattens the racial ambiguity in the text by depicting him as very white and her as very black (ASSIS, 1959, p. 26).

To my knowledge, there were at least two other translations that preceded Caldwell's. Jean Duriau's French translation, "Un père contre une mère," appeared in the Revue de l'Amérique latine in 
In fairness to anyone who has ever misunderstood this sentence, even my iPhone autocorrects acoitar to açoitar. Since our technology both reflects and affects us, perhaps this, our twenty-first century way of setting type, corresponds to the evolution of how the story has been read over time as one word has become more common than the other. ${ }^{18}$ After all, nothing indicates that the first Garnier edition was in error. The majority of subsequent releases of the story do not incorporate the cedilha, including, as previously mentioned, the 1975 Civilização Brasileira critical edition that scholars consider to be the most trustworthy source. ${ }^{19}$ Furthermore, a survey of the runaway slave ads placed in papers such as Rio's Jornal do Commercio in the mid-to-late nineteenth century shows that some subset of the elements Machado identifies appear in almost every single ad. Permutations of the commonplace phrase "Protesta-se com todo o rigor da lei contra quem o tiver acoutado" never carry a cedilha. ${ }^{20}$

1926. Though he does correctly interpret "acoutasse," he includes a translator's note claiming that "les esclaves n'étaient pas maltraités au Brésil" in Machado's time, which is reminiscent of the sentiment that the law would hold anyone who beat runaways accountable (ASSIS, 1926, p. 514). G. Alpi's Italian translation, "Padre contro madre," published in La Rassegna Italiana in 1929, carries the peculiar caption "Nel mondo di Braz Cubas" above the title and is followed by some exaggerated notes on Machado that claim he was neither popular nor understood outside a small circle of friends (ASSIS, 1929).

18 The fact that there has been an increase in the number of editions over the last twenty years that footnote the word lends credence to this idea.

${ }^{19}$ Just two sentences before "acoutasse," the critical edition even takes pains to footnote the fact that the quotation marks have been moved from outside the punctuation to inside it. Therefore, it is unlikely that the possibility of a cedilha would go unnoticed or unremarked.

It is particularly ironic that Brayner's anthology should contain the error given that it was produced by the exact same publisher - Civilização Brasileira, in partnership with the Instituto Nacional do Livro - that released the critical edition five years previously. In her own words, "Os textos da presente antologia foram [...] os consagrados como definitivos pela Comissão Machado de Assis, reunida para a elaboração das edições críticas do autor" (BRAYNER, 1980, p. 18). As previously noted, the Global collection also traces its textual roots to the same source. Domício Proença Filho (1994, p. 15) asserts the following in his introduction: "Transcrevi, com a necessária atualização ortográfica, os textos que a Comissão Machado de Assis considerou definitivos". It is perhaps unlikely that he transcribed the text personally, but, in Proença's defense, the word in question did match the established critical text until 1994.

20 Despite its ubiquity and the lack of ambiguity in variants like "quem lhe der couto," the word "acoutar" continues to be frequently misread or misquoted in the context of runaway slave ads. Literally thousands of them are publicly accessible in the nineteenth-century periodicals on the website of the Biblioteca Nacional. In the few hundred that I had the patience to review, I encountered many variations of both "acoutar" and "acoitar" - sometimes even in reference to missing dogs - but never found a single cedilha as part of the "Protesta-se" stock phrase.

Yet, as evidence of how widespread this problem is, even scholars continue to get it wrong. For example, the historian José Leonardo do Nascimento (2006, p. 76, emphasis mine), referring to these runaway slave notices, observes that "Os proprietários prometiam recompensar aos que informassem sobre os fujões e processar os que lhes açoitassem". He then quotes an ad on page four of the January 
At any rate, especially when understood in the context of the period, the weight of the evidence makes it abundantly clear that the correct form is, as it originally appeared, "acoutasse" with a hard c. I am not convinced that there is anything to be gained in further identifying occurrences of açoutasse / açoitasse in "Pai contra mãe" or tracing its spread beyond what I have already done. ${ }^{21}$ On a practical level, tracking down every last version of the story ever issued in print or electronic format seems both a tedious and useless exercise when the original intent is not in doubt and the text is in the public domain. What matters most is not when the typo first appeared, but that 1) it exists, and in all likelihood can never be done away with at this point; and 2) it has made concrete how some people have read - and always will read - the passage. The most fascinating detail about this particular typo is not that it makes sense, but that those responsible for it, on separate occasions and independent of one another, did not introduce it out of carelessness, as Cândido Neves the typesetter might have. Rather, it is most probable that they believed they were, in fact, correcting a typo. If, as Hélio de Seixas Guimarães (2017a, p. 279) has suggested, meaning in Machado's work depends on "onde o leitor se situa em relação ao texto," there is poetry in the idea that the way readers understand this passage has had a real, tangible effect on the text.

Nevertheless, there is also a more somber dimension to the appearance of the cedilha. The etymology of the word "typo" or "tipo," as in "erro tipográfico," comes to us through Latin (typus) from Greek - specifically,

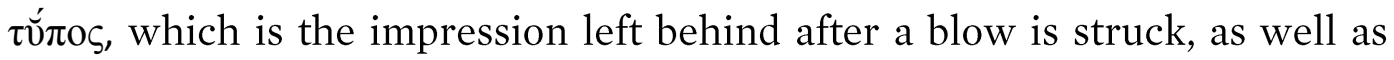
the verb $\tau$ vi $\tau \omega$, meaning "I strike" or "I beat." The connection to the mechanics of early type and printing is obvious, but in this context, it cannot help but take on other, grimmer implications. It reminds us of the "sinais" Machado cites in the runaway notices, which, like the "cicatriz na testa" of

15, 1878 edition of A Província de São Paulo: "protesta-se com todo o rigor da lei contra quem os tiver açoitado" (NASCIMENTO, 2006, p. 76, emphasis mine). Nevertheless, a quick perusal of A Província on that date reveals that the ad actually reads "contra quem os tiver acoutado" (FUGIRAM, 1878, p. 4, emphasis mine).

To be fair to Nascimento, a few pages later he cites the crucial passage in "Pai contra mãe" accurately ("acoutasse," NASCIMENTO, 2006, p. 81) before noting that "Os proprietários ameaçavam com 'o rigor da lei' os que protegessem ou 'acoitassem' negros foragidos" (NASCIMENTO, 2006, p. 82). When understood literally, both his previous comment using "açoitar" and this one are plausible, but the primary source does not support the former. N.B.: My caveat in note 15 also applies here.

${ }^{21}$ In print alone, I have examined close to ninety examples of the story, including every version published before it entered the public domain. 
eleven-year-old Lucrécia in "O caso da vara," ${ }^{22}$ were usually the work of their owners' blows. For example, note the language of this notice that appeared on page 3 of the Correio Paulistano on February 7, 1880:

Fugio da fazenda de Francisco Prudente José Corrêa o escravo Agostinho, [...] tem um signal no pescoço (de ferro) e este recente [...]; este escravo foi a dois mezes submettido a julgamento no jury desta cidade e sendo condemnado a açoutes tem signal de castigo nas nadegas. Este escravo esteve acoitado nesta cidade pelo espaço de 10 mezes negociando durante a noite no centro da cidade, conforme declarou. [...] Gratifica-se com a quantia acima [400\$000] a quem o prender e entregar ao seu referido senhor.

Protesta se usar de todo o rigor da lei contra aquelle que o acoitar (CASA..., 1880, p. 3, emphasis mine). ${ }^{23}$

The extra mark on Machado's text, the cedilha that can never be erased and is now forever part of the story, was intended as correction... and so too were these "sinais," a term that, make no mistake, is a euphemism for scars. The sardonic, expository nature of the opening of "Pai contra mãe" makes it appear that Machado thought it necessary to remind his readers of the horrors of slavery's heyday some years after it had ceased (CHALHOUB, 2016, p. 65). In this context, the cedilha, which resembles both a whip and the wounds it inflicts, becomes a textual memorial as well. Furthermore, it is a Borgesian Aleph of the story as a whole. Like this runaway notice, which sets both the word "acoitado" and descriptions of the effects of "açoutes" together in type, the cedilha becomes a typographical bridge between acoitar and açoitar, simultaneously illuminating the counterpoint that drives the

\footnotetext{
${ }^{22}$ When Sinhá Rita warns her to mind the rod, "A pequena abaixou a cabeça, aparando o golpe, mas o golpe não veio. Era uma advertência; se à noitinha a tarefa não estivesse pronta, Lucrécia receberia o castigo do costume. Damião olhou para a pequena; era uma negrinha, magricela, um frangalho de nada, com uma cicatriz na testa e uma queimadura na mão esquerda" (ASSIS, 2015d, p. 526).

${ }^{23}$ Lília Moritz Schwarcz's Retrato em branco e negro refers to this same notice, though dated February 10 (the ad appeared, without variation, on February 7, 10, 12, and 13). Among other errors, part of her transcription reads: "Esteve açoitado por dez mezes" (SCHWARCZ, 1987, p. 145, emphasis mine). Unlike in the more common phrase Machado alludes to, "açoitado" does not make sense in this context.

Later in the book, on the fourth page of a section of un-paginated images between pages 256 and 257, Schwarcz also reproduces a facsimile of a runaway advertisement, identifying the Correio Paulistano from January 29,1878 as its source (though no such ad appears in the CP on that date). This notice includes the phrase "Protesta-se contra quem o tiver acoutado com o rigor da lei" and is frequently referenced by others, citing Schwarcz's book, but - ironically - with "acoutado" changed to "açoitado." N.B.: My caveat in note 15 also applies here.
} 
narrative while also encompassing it in a single point. Consequently, the act of reading is transformed into a performative ritual that reenacts the choice of Cândido Neves, Coutinho, or Damião: As readers encounter the word in question, consciously or not, cedilha or not, they also choose between acoitar and açoitar. This is not just father against mother, it is beat versus abet, it is author versus reader.

\section{Conclusion}

Though the fault for the cedilha in Sônia Brayner's and Domício Proença Filho's anthologies most likely lies with copy editors, it feels only fair that the people whose names are on the covers should have a word. Brayner (1979, p. 66) has identified "a máxima ambiguidade da palavra" as one of the prime virtues of Machado's post-1880 short stories. Proença Filho (1994, p. 9-10) affirms "multissignificação" as one of literature's essential characteristics and part of what makes Machado's work timeless particularly his "oscilações entre o Bem e o Mal," which map uncannily well on "to beat or abet." So it is fitting that Brayner's and Proença's editions of "Pai contra mãe" have ended up enhancing precisely these qualities: they have served to maximize both the ambiguity of a single word as well as the multi-signification of the overall text.

In Dom Casmurro, Bento remarks that "Assim preencho as lacunas alheias; assim podes também preencher as minhas" (ASSIS, 2015b, p. 968). Yet the ultimate fate of the lacuna below the $c$ - literally in the "entrelinhas" - depends on both the reader's version of the story and how their mind interprets the word. ${ }^{24}$ This does not mean that it is a dichotomy, exactly. ${ }^{25}$ Rather, it is like a textual Schrödinger's cat - the printed word is both acoitar and açoitar until the book is opened, the word is read, and our intervention determines the text. To borrow words from Riobaldo, the cedilha "é e não é"

\footnotetext{
${ }^{24}$ Though not touching on the issue of the cedilha specifically, Giulia Ricco (2016, p. 247) nevertheless evokes it by pointing out that, in this story, "violence hides in what [...] is left unsaid".

25 Referring to both the title and the "Entreaberto botão, entrefechada rosa" of Machado's poem "Menina e moça," Tosta (2004, p. 38) writes: "Apesar de destacar as duas partes que compõem o 'todo', Machado deixa bem claro que este é indivisivel e que os dois pólos, apesar de distintos, estão entrelaçados entre si." Using this as an organizational metaphor for the "entre-lugar" in Machado, Tosta goes on to analyze the tension between author, text, reader, and narrator in several examples of his work. All participants combine their efforts to forge a self-renewing literary cycle because even attempts to "fechar" (definitively interpret) the text contribute to opening it up again (TOSTA, 2004, p. 50-51).
} 
at the same time (ROSA, 2001, p. 27). It remains in quantum superposition ${ }^{26}$ until it is measured by the act of reading, forcing it to collapse into $c$ or $c$. Similar to the alleged adultery of Capitu in Dom Casmurro, the cedilha is a microcosm of the ambiguity inherent in Machado's writing - be it whether Cândido and Clara Neves are black or white, whether Cândido's choice is individual or systemic, whether there is Natal or miscarriage, or whether the word is acoitar or açoitar. What matters most is that the paradox exists in the first place. As only Machado can illustrate, people with good intentions do terrible things, even against their own, which is why stories like "Pai contra mãe" are so frightening. Both acoitar and açoitar are crucial parts of the narrative because they are written in our hearts, and they can no more be separated from each other than can the text from the reader.

\section{Acknowledgements}

I would like to express my gratitude to the following people for either assisting me in obtaining a translation of "Pai contra mãe" or helping me navigate one of the languages I do not speak: Margaret Jull Costa, Alison Entrekin, Katharina Gerstenberger, Bethania Guerra de Lemos, Kristen Ullrich Hodges, Eric R. Laursen, Joseph R. Metz, Wiltrud Mihatsch, Carlos Alberto Pasero, Robin Patterson, Pablo Cardellino Soto, and Margaret M. Toscano. Special thanks also to Cristiane Lira, Frederick G. Williams, Vanessa Fitzgibbon, and the late Nicolau Sevcenko for their contributions.

\section{References}

ANDRADE, Mário de. Machado de Assis. In: Obras completas de Mário de Andrade. São Paulo: Martins, 1950-1959. v. 10: Aspectos da literatura brasileira, p. 89-108.

ASSIS, Machado de. Pai contra mãe. In: Relíquias de casa velha. Rio de Janeiro: Garnier, 1906. p. 3-17.

Un père contre une mère. Translated by Jean Duriau. Revue de l'Amérique latine, Paris, v. XI, n. 33, p. 513-525, juin 1926.

. Padre contro madre. Translated by G. Alpi. La Rassegna Italiana, Rome, v. 24, p. 629-637, 1929.

${ }^{26}$ Thanks to Asa Laws for suggesting this term. 
Отец против матери [Otets protiv materi]. In: НИкOHOBA, B. [NIKONOV, V.] (Ed. and trans.). Бразильские рассказы [Brazil'skie rasskazy]. Москва [Moskva]: Государственное издательство художественной литературы [Izdat. Chudož. Liter.], 1959. p. 26-36.

Father versus Mother. In: The Psychiatrist and Other Stories. Translated by Helen Caldwell. Berkeley: University of California Press, 1963a. p. 101-112.

Pai contra mãe. In: Relíquias de casa velha. São Paulo: Instituto de Divulgação Cultural, 1963b. v. 1, p. 9-18. Vater gegen Mutter. In: Meistererzählungen des Machado de Assis. Translated by Curt Meyer-Clason. [Hamburg]: Chr. Wegner, 1964. p. 278-292. Pai contra mãe. In: O conto de Machado de Assis. Seleção, introdução e organização de Sônia Brayner. Rio de Janeiro: Civilização Brasileira; INL, 1980. p. 282-291.

Pai contra mãe. In: Os melhores contos de Machado de Assis. 9. ed. rev. e ampl. Seleção de Domício Proença Filho. São Paulo: Global, 1994. p. 249-258. Father against Mother. In: A Chapter of Hats and Other Stories. Translated by John Gledson. London: Bloomsbury, 2008. p. 255-270.

Father against Mother. In: The Alienist and Other Stories of Nineteenth-Century Brazil. Edited and translated by John Charles Chasteen. Indianapolis: Hackett, 2013. p. 61-73. Advertência. In: Obra completa em quatro volumes. Organização de Aluizio Leite, Ana Lima Cecílio, Heloísa Jahn e Rodrigo Lacerda. Rio de Janeiro: Nova Aguilar, 2015a. v. 2, p. 620.

Dom Casmurro. In: Obra completa em quatro volumes. Organização de Aluizio Leite, Ana Lima Cecílio, Heloísa Jahn e Rodrigo Lacerda. Rio de Janeiro: Nova Aguilar, 2015b. v. 1, p. 904-1043.

Mariana. In: Obra completa em quatro volumes. Organização de Aluizio Leite, Ana Lima Cecílio, Heloísa Jahn e Rodrigo Lacerda. Rio de Janeiro: Nova Aguilar, 2015c. v. 2, p. 978-990. O caso da vara. In: Obra completa em quatro volumes. Organização de Aluizio Leite, Ana Lima Cecílio, Heloísa Jahn e Rodrigo Lacerda. Rio de Janeiro: Nova Aguilar, 2015d. v. 2, p. 524-529. O enfermeiro. In: Obra completa em quatro volumes. Organização de Aluizio Leite, Ana Lima Cecílio, Heloísa Jahn e Rodrigo Lacerda. Rio de Janeiro: Nova Aguilar, 2015e. v. 2, p. 480-485.

O espelho: esboço de uma nova teoria da alma humana. In: Obra completa em quatro volumes. Organização de Aluizio Leite, Ana Lima Cecílio, Heloísa Jahn e Rodrigo Lacerda. Rio de Janeiro: Nova Aguilar, 2015f. v. 2, p. 313318. 
Pai contra mãe. In: Obra completa em quatro volumes. Organização de Aluizio Leite, Ana Lima Cecílio, Heloísa Jahn e Rodrigo Lacerda. Rio de Janeiro: Nova Aguilar, 2015g. v. 2, p. 621-627.

Um homem célebre. In: Obra completa em quatro volumes. Organização de Aluizio Leite, Ana Lima Cecílio, Heloísa Jahn e Rodrigo Lacerda. Rio de Janeiro: Nova Aguilar, 2015h. v. 2, p. 451-457. Father against Mother. In: The Collected Stories of Machado de Assis. Translated by Margaret Jull Costa and Robin Patterson. New York: Liveright, 2018. Forthcoming.

BRAYNER, Sônia. Labirinto do espaço romanesco. Rio de Janeiro: Civilização Brasileira; INL, 1979.

Texto e cronologia de publicação. In: ASSIS, Machado de. $O$ conto de Machado de Assis. Seleção, introdução e organização de Sônia Brayner. Rio de Janeiro: Civilização Brasileira; INL, 1980. p. 18-19.

BROOKSHAW, David. Race and Color in Brazilian Literature. Metuchen (NJ); London: The Scarecrow Press, 1986.

CASA branca escravo fugido. Correio Paulistano, São Paulo, 7 fev. 1880. p. 3.

CHALHOUB, Sidney. The Legacy of Slavery: Tales of Gender and Racial Violence in Machado de Assis. In: AIDOO, Lamonte; SILVA, Daniel F. (Org.). Emerging Dialogues on Machado de Assis. New York: Palgrave, 2016. p. 55-69.

DANIEL, Reginald. Machado de Assis: Multiracial Identity and the Brazilian Novelist. University Park: The Pennsylvania State University Press, 2012.

DIXON, Paul. Machado de Assis's Early Mulato Narratives. Afro-Hispanic Review, Nashville (TN), v. 29, n. 2, p. 39-54, 2010.

DUARTE, Eduardo de Assis. Estratégias de caramujo. In: (Org.). Machado de Assis afro-descendente. Rio de Janeiro: Pallas; Belo Horizonte: Crisálida, 2007a. p. 239-278.

Machado de Assis's African Descent. Research in African Literatures, Bloomington (IN), v. 38, n. 1, p. 134-151, 2007b.

FAORO, Raymundo. Machado de Assis: a pirâmide e o trapézio. 2. ed. São Paulo: Companhia Editora Nacional, 1976.

FLYNN, Alex; CALVO-GONZÁLEZ, Elena; SOUZA, Marcelo Mendes de. Whiter Shades of Pale: "Coloring in" Machado de Assis and Race in Contemporary Brazil. Latin American Research Review, Pittsburgh (PA), v. 48, n. 3, p. 3-24, 2013.

FRANÇA NETO, João Irineu de. A representação da escravidão nos contos de Machado de Assis. 2008. 127 f. Dissertação (Mestrado em Letras) - Centro de Ciências Humanas, Letras e Artes, Universidade Federal da Paraíba, João Pessoa, 2008.

FUGIRAM. A Província de São Paulo, São Paulo, 5 jan. 1878. p. 4.

GUIMARÃES, Hélio de Seixas. Machado de Assis, o escritor que nos lê: as figuras machadianas através da crítica e das polêmicas. São Paulo: Editora Unesp, 2017a. 
Race and Color in the Reception of Machado de Assis. Luso-Brazilian Review, Madison (WI), v. 54, n. 2, p. 11-28, $2017 \mathrm{~b}$.

LEWIS, Christopher T. Machado de Assis's Dom Casmurro and "Soneto de Natal": The Calculated Mediocrity of a Mute Prophet. Hispania, Baltimore (MD), v. 99, n. 4, p. 553-562, 2016.

LIMA, Célia; RODRIGUES, J. Machado de Assis: Pai contra mãe. In: CAVAlCANTE, Djalma (Org.). Contos em quadros. Juiz de Fora (MG): Editora UFJF; São Paulo: Musa Editora, 2003. p. 6-19.

MACHADO, Ubiratan. Machado de Assis e Cruz e Sousa. In: Três vezes Machado de Assis. São Paulo: Ateliê Editorial, 2007. p. 45-53.

MAGALHÃES JÚNIOR, Raimundo. Machado de Assis desconhecido. 3. ed. Rio de Janeiro: Civilização Brasileira, 1957.

MAROTTI, Giorgio. Black Characters in the Brazilian Novel. Translated by Maria O. Marotti and Harry Lawton. Los Angeles: Center for Afro-American Studies, University of California, 1987.

NASCIMENTO, José Leonardo do. Modernidade e escravidão na imprensa brasileira no final do século XIX. Clio - Revista do Centro de História da Universidade de Lisboa, Lisboa, v. 14, p. 69-90, 2006.

NEWCOMB, Robert. Machado de Assis and English Social Contract Theory: A Reading of "Pai contra mãe." Espelho - Revista Machadiana, Porto Alegre, v. 14/15, p. 34-63, 2008-2009.

PROENÇA FILHO, Domício. Permanência e atualidade da ficção machadiana. In: ASSIS, Machado de. Os melhores contos de Machado de Assis. 9. ed. rev. e ampl. Seleção de Domício Proença Filho. São Paulo: Global, 1994. p. 9-16.

RICCO, Giulia. Framing Violence: Narrator and Reader in "Pai contra mãe." In: AIDOO, Lamonte; SILVA, Daniel F. (Org.). Emerging Dialogues on Machado de Assis. New York: Palgrave, 2016. p. 239-249.

ROCHA, Fernando Sousa de. "Father versus Mother": Slavery and Its Apparatuses. In: AIDOO, Lamonte; SILVA, Daniel F. (Org.). Emerging Dialogues on Machado de Assis. New York: Palgrave, 2016. p. 91-103.

ROSA, João Guimarães. Grande sertão: veredas. 19. ed. Rio de Janeiro: Nova Fronteira, 2001.

SAYERS, Raymond S. The Negro in Brazilian Literature. New York: Hispanic Institute in the United States, 1956.

SCHWARCZ, Lília Moritz. Retrato em branco e negro: jornais, escravos e cidadãos em São Paulo no final do século XIX. São Paulo: Companhia das Letras, 1987.

TOSTA, Antonio Luciano. Machado de Assis: a obra entreaberta. Luso-Brazilian Review, Madison (WI), v. 41, n. 1, p. 37-55, 2004.

WILLIAMS, Frederick G. Re: Helen Caldwell. [Personal correspondence]. Email received by the author on 30 Oct. 2017.

WISNIK, José Miguel. Machado maxixe: o caso Pestana. São Paulo: Publifolha, 2008. 


\section{Appendix: Translations of "Pai contra mãe"}

Dutch

1986 WILLEMSEN, August (Trans.). Vader tegen Moeder. In: ASSIS, Machado de. Vrouwenarmen en andere Verhalen. Amsterdam: De Arbeiderspers, cop. 1986. p. 146-159.

\section{English}

1963 CALDWELL, Helen (Trans.). Father versus Mother. In: ASSIS, Machado de. The Psychiatrist and Other Stories. Translated by William L. Grossman and Helen Caldwell. Berkeley: University of California Press, 1963. p. 101-112.

2008 GLEDSON, John (Trans.). Father against Mother. In: ASSIS, Machado de. A Chapter of Hats and Other Stories. London: Bloomsbury, 2008. p. 255-270.

2013 CHASTEEN, John Charles (Trans.). Father against Mother. In: ASSIS, Machado de. The Alienist and Other Stories of Nineteenth-Century Brazil. Indianapolis (IN): Hackett, 2013. p. 61-73.

2018 COSTA, Margaret Jull; PATTERSON, Robin (Trans.). Father against Mother. In: ASSIS, Machado de. The Collected Stories of Machado de Assis. New York: Liveright, 2018. Forthcoming.

French

1926 DURIAU, Jean (Trans.). Un père contre une mère. By Machado de Assis. Revue de l'Amérique Latine, Paris, 5e année, v. XI, n. 33, juin 1926, p. 513-525.

2006 QUINT, Anne-Marie (Trans.). Chasseur d'esclaves: un père contre une mère. By Machado de Assis. Paris: Éditions Chandeigne, 2006.

\section{German}

1964 MEYER-CLASON, Curt (Trans.). Vater gegen Mutter. In: ASSIS, Machado de. Meistererzählungen des Machado de Assis. [Hamburg]: Chr. Wegner, 1964, p. 278-292.

\section{Italian}

1929 ALPI, G. (Trans.). Padre contro madre. By Machado de Assis. La Rassegna Italiana, Rome, anno XII, v. 24, 1929. p. 629-637.

1990 MUNNO, Amina Di (Trans.). Padre contro madre. In: ASSIS, Machado de. La cartomante e altri racconti. Torino: Einaudi, 1990. p. 175-185. 
2002 GIORGI, Giuliana Segre (Trans.). Padre contro madre. In: ASSIS, Machado de. Galleria postuma e altri racconti. Torino: Lindau, 2002, p. 81-95.

2007 ZANOLLA, Virgilio (Trans.). Padre contro madre. By Machado de Assis. In: (Org.). La brasiliana svelata: storia mai raccontata della più grande narrativa del Sud America (1870-1922). Torino: Robin Edizioni, 2007, p. 249-264.

Russian

1959 НИКОНОВА, В. [Nikonov, V.] (Trans.). Отец против матери [Otets protiv materi]. By Machado de Assis. In: (Ed. and trans.). Бразильские рассказы [Brazil'skie rasskazy]. Москва [Moskva]: Государственное издательство художественной литературы [Izdat. Chudož. Liter.], 1959. p. 26-36.

Spanish

1978 KOVADLOFF, Santiago (Trans.). Padre contra madre. In: ASSIS, Machado de. Cuentos. Selección y prólogo de Alfredo Bosi. Caracas: Biblioteca Ayacucho: 1978. p. 253-262.

1996 PASERO, Carlos Alberto (Trans.). Padre contra madre. By Machado de Assis In:__ (Org.). Cuentos del Brasil. Buenos Aires: Kapelusz, 2002. p. 45-57.

2011 GUERRA DE LEMOS, Bethania; BAUTISTA RODRÍGUEZ, Juan (Trans.). Padre contra madre. In: ASSIS, Machado de. Cuentos de madurez. Valencia: Editorial Pre-Textos, 2002. p. 437-454.

2013 ROCCA, Pablo (Trans.). Padre contra madre. In: ASSIS, Machado de. Confesiones de una viuda joven y otros cuentos. Prólogo de João Cezar de Castro Rocha. Montevideo: Ediciones de la Banda Oriental, 2013. p. 113-125.

2017 EGUILUZ, Magalí (Trans.). Padre contra madre. By Machado de Assis. Ficciones en traducciones, Santa Fe, Universidad Nacional de Rosario, 11 sept. 2017. Available at: <http://ficcionesentraduccion.unr.edu.ar/?p=85>. Accessed on: 15 Nov. 2017.

CHRISTOPHER T. LEWIS is Assistant Professor of Portuguese \& Brazilian Studies at the University of Utah (Salt Lake City, UT, EUA), where he directs the Portuguese program and teaches Luso-Brazilian culture, literature, and film. He holds a Ph.D. in Romance Languages \& Literatures, with an emphasis in Portuguese \& Luso-Brazilian Literatures, from Harvard University. Some of his recent publications have appeared in Hispania, LusoBrazilian Review, and Chasqui. Email: christopher.t.lewis@utah.edu 